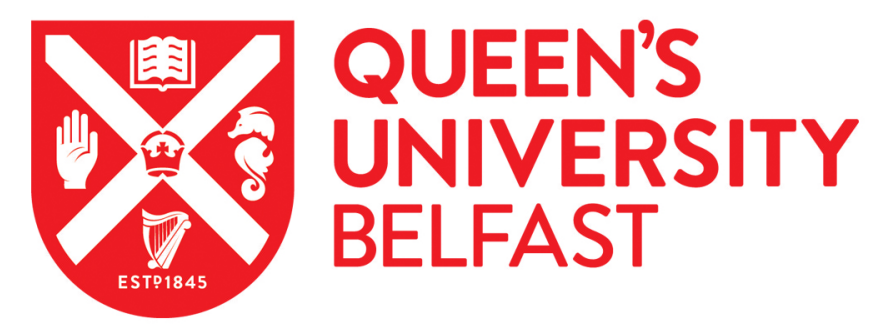

\title{
Short-term immobilization of ammonium and nitrate added to a grassland soil
}

Christie, P., \& Wasson, E. A. (2001). Short-term immobilization of ammonium and nitrate added to a grassland soil. Soil Biology and Biochemistry, 33(9), 1277-1278.

Published in:

Soil Biology and Biochemistry

Queen's University Belfast - Research Portal:

Link to publication record in Queen's University Belfast Research Portal

\section{General rights}

Copyright for the publications made accessible via the Queen's University Belfast Research Portal is retained by the author(s) and / or other copyright owners and it is a condition of accessing these publications that users recognise and abide by the legal requirements associated with these rights.

Take down policy

The Research Portal is Queen's institutional repository that provides access to Queen's research output. Every effort has been made to ensure that content in the Research Portal does not infringe any person's rights, or applicable UK laws. If you discover content in the Research Portal that you believe breaches copyright or violates any law, please contact openaccess@qub.ac.uk. 


\title{
Short-term immobilization of ammonium and nitrate added to a grassland soil
}

\author{
P. Christie*, E.A. Wasson \\ Agricultural and Environmental Science Division, Department of Agriculture and Rural Development, Newforge Lane, Belfast BT9 5PX, UK
}

Received 6 March 2000; received in revised form 15 August 2000; accepted 6 September 2000

\begin{abstract}
Short-term immobilization of added ${ }^{15} \mathrm{NH}_{4}^{+}-\mathrm{N}$ and ${ }^{15} \mathrm{NO}_{3}^{-}-\mathrm{N}$ (with or without added glucose) was determined at time intervals in a preconditioned grassland soil over laboratory incubation periods of up to 15 days at $25 \mathrm{C}$. Exchangeable $\mathrm{N}$ was removed from soil sub-samples by repeated $2 \mathrm{~m} \mathrm{KCl}$ extraction and centrifugation. The solid residues were immediately blast frozen, freeze-dried and analysed for total $\mathrm{N}$ and $\mathrm{N}$ isotope ratio. Sub-samples without glucose amendment showed very little immobilization of added $\mathrm{N}\left(5\right.$ and $<2 \%$ of added $\mathrm{NH}_{4}^{+}-\mathrm{N}$ and $\mathrm{NO}_{3}^{-}-\mathrm{N}$ respectively after 15 days). In contrast, when glucose was added, $16 \%$ of added $\mathrm{NH}_{4}^{+}-\mathrm{N}$ and $8 \%$ of added $\mathrm{NO}_{3}^{-}-\mathrm{N}_{\text {appeared to be }}$ immobilized, and most immobilization occurred within about 3 days of $\mathrm{N}$ application. This preliminary experiment indicates that this simple method could be used routinely to compare the $\mathrm{N}$ immobilization potentials of different soils. (C) 2001 Elsevier Science Ltd. All rights reserved.
\end{abstract}

Keywords: Ammonium; Nitrate; Short-term immobilization; Grassland soil

Net rates of immobilization of $\mathrm{NH}_{4}^{+}$and $\mathrm{NO}_{3}^{-}$by the soil microbial biomass have been measured under field conditions over long periods using ${ }^{15} \mathrm{~N}$ techniques. For example, Puri and Ashman (1999) found that $\mathrm{NH}_{4}^{+}$showed twice the immobilization rate of $\mathrm{NO}_{-}$on average in an acid woodland soil over 12 months under field conditions. The preferential microbial uptake of $\mathrm{NH}_{4}^{+}$rather than $\mathrm{NO}_{3}^{-}$has also been demonstrated in several studies including Jackson et al. (1989); Recous and Mary (1990); Recous et al. (1992); Rice and Tiedje (1989); Wickramasinge et al. (1985). Puri and Ashman (1999) found a relatively low ratio of $\mathrm{NH}_{4}^{+}$to $\mathrm{NO}_{3}^{-}$immobilization in their woodland soil and pointed out that this ratio is likely to vary among soil types. This paper describes a very simple laboratory incubation technique that could be used as a routine method for comparing the $\mathrm{N}$ immobilization potential of different soils and presents some results from a preliminary experiment on a temperate grassland soil.

A clay loam grassland soil (Typic Dystrochrept) with a $\mathrm{pH}$ (in $\mathrm{H}_{2} \mathrm{O}$ ) of $6.0,0.34 \% \mathrm{~N}$ and $3.7 \%$ C overlying Silurian shale and greywacke was used. Soil was collected from the top $7.5 \mathrm{~cm}$ of the profile at the Agricultural Research Insti-

\footnotetext{
* Corresponding author. Tel.: +44-28-9025-5335; fax: +44-28-90662007.

E-mail address: peter.christie@dardni.gov.uk (P. Christie).
}

tute of Northern Ireland at Hillsborough, County Down (O.S. Grid Reference J 244577). Sixty sub-samples (50 g) of air dried sieved $(<2 \mathrm{~mm})$ soil were adjusted to $75 \%$ of water holding capacity (WHC) in $500 \mathrm{~cm}^{3}$ polyethylene bottles and pre-incubated at $25 \mathrm{C}$ for 2 weeks with loose screw caps to allow gas exchange. Two aqueous solutions of inorganic $\mathrm{N}$ were prepared: $12.26 \mathrm{~g} \mathrm{l}^{-1} 99.7$ atom \% $\left({ }^{15} \mathrm{NH}_{4}\right)_{2} \mathrm{SO}_{4}$ and $18.25 \mathrm{~g} \mathrm{l}^{-1} 99.4$ atom $\% \mathrm{~K}^{15} \mathrm{NO}_{3}$. The solutions were also prepared containing $31.64 \mathrm{~g} \mathrm{l}^{-1} \mathrm{D}$ glucose, giving a total of four solutions. A $5-\mathrm{ml}$ aliquot of each solution was applied evenly by pipette to the surface of 15 replicate sub-samples of pre-conditioned soil. Thus $\mathrm{NH}_{4}^{+}-\mathrm{N}$ and $\mathrm{NO}_{3}^{-}-\mathrm{N}$ were applied at $27 \mathrm{mg}$ per $100 \mathrm{~g}$ of soil with or without $130 \mathrm{mg} \mathrm{C}$ (as glucose) per $100 \mathrm{~g}$. This addition of $\mathrm{N}$ was selected to be approximately equivalent to an application rate of $200 \mathrm{~kg} \mathrm{~N} \mathrm{ha}^{-1}$, the rate equivalent on average to herbage offtake in cut grass at the sampling site.

The $\mathrm{N}$ and $\mathrm{N}+\mathrm{C}$ solutions were applied evenly to the surfaces of the soil samples by pipette and the soils were then adjusted to WHC by surface application of deionized water to transport the added $\mathrm{C}$ and $\mathrm{N}$ into the soil. The soils were incubated at $25 \mathrm{C}$ for $0,1,3,7$ or 15 days when triplicate sub-samples were removed and re-adjusted to WHC. Exchangeable $\mathrm{N}$ was extracted by adding $2 \mathrm{~m} \mathrm{KCl}$ $(125 \mathrm{ml})$ to each sample and shaking for $30 \mathrm{~min}$. The suspensions were centrifuged for $30 \mathrm{~min}$ at $1000 \mathrm{rpm}$ at 


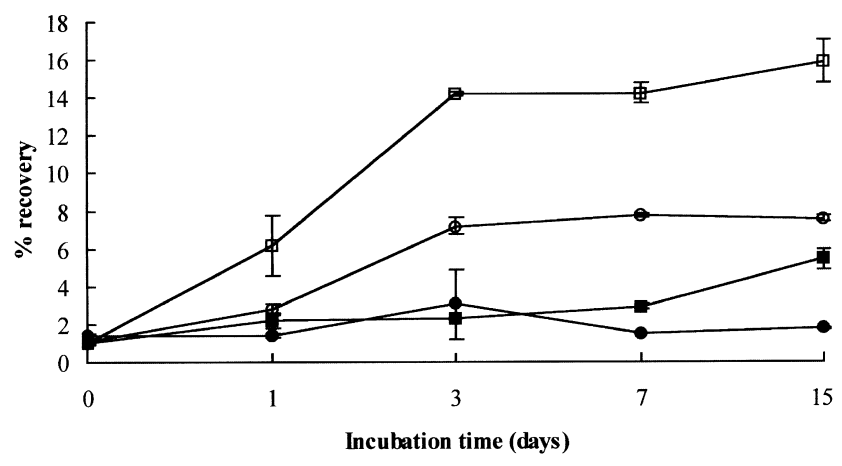

Fig. 1. Percent recovery of added $\mathrm{N}$ in soil residue following $\mathrm{KCl}$ extraction at different times from $\mathrm{N}$ addition during incubation at $25^{\circ} \mathrm{C}$. Treatments: $\boldsymbol{\square}, \mathrm{NH}_{4} ; \square, \mathrm{NH}_{4}+\mathrm{C} ; \boldsymbol{\bullet}, \mathrm{NO}_{3} ; \mathrm{O}, \mathrm{NO}_{3}+\mathrm{C}$. Bars: standard error of the mean.

0-5 C. Extraction and centrifugation was repeated twice to give three $\mathrm{KCl}$ extractions in total to ensure complete removal of inorganic $\mathrm{N}$ (Widmer et al., 1989). The residues from the centrifugation stage were immediately blast frozen and freeze dried to prevent further biological or chemical changes. The dried residues were ball-milled to pass a $150 \mu \mathrm{m}$ sieve and total $\mathrm{N}$ was determined by dry combustion using a Carlo Erba Model 1500 Nitrogen Analyzer and $\mathrm{N}$ isotope ratio was determined using a VG Micromass Model 622 mass spectrometer. No attempt was made to determine gaseous losses of applied $\mathrm{N}$ from the soil. The study was restricted to immobilization of applied $\mathrm{N}$.

The percent recovery of added $\mathrm{N}$ in the soil residues is shown in Fig. 1. As expected, the pre-conditioning incubation of the soil had allowed microbial activity to utilize substrates released as a result of disturbance during the setting up of the sub-samples, and thus the aliquots not amended with glucose showed very little immobilization of added $\mathrm{N}\left(5 \%\right.$ and under $2 \%$ of added $\mathrm{NH}_{4}^{+}-\mathrm{N}$ and $\mathrm{NO}_{3}^{-}-\mathrm{N}$ respectively after 15 days). In contrast, when glucose was added as $\mathrm{C}$ substrate, $16 \%$ of added $\mathrm{NH}_{4}^{+}-\mathrm{N}$ and $8 \%$ of added $\mathrm{NO}_{3}^{-}-\mathrm{N}$ were immobilized, and most immobilization occurred within about 3 days of $\mathrm{N}$ application. Thus $\mathrm{NH}_{4}^{+}$showed twice the immobilization rate of $\mathrm{NO}_{3}^{-}$when $\mathrm{C}$ substrate was available for microbial activity, a ratio in accord with those of Puri and Ashman (1999) in an acid temperate woodland soil ( $\mathrm{pH}$ 3.9) but lower than those reported in other studies (Recous and Mary, 1990; Recous et al., 1992).

The small recoveries of added $\mathrm{NH}_{4}^{+}$and $\mathrm{NO}_{3}^{-}$immobilized in the absence of added glucose $(5$ and $<2 \%$ respectively) may represent non-microbial fixation to give nonexchangeable $\mathrm{NH}_{4}^{+}$(Mulvaney, 1996) and abiotically immobilized $\mathrm{NO}_{3}^{-}$(Azhar et al., 1986). These could perhaps be regarded as control values that could be subtracted from the results with glucose amendment to give a more accurate estimate of microbial immobilization. With some further development this relatively simple method could be used to compare the immobilization ratios of $\mathrm{NH}_{4}^{+}$to $\mathrm{NO}_{3}^{-}$in a wide range of soils under standardized conditions without the complications and assumptions required for ${ }^{15} \mathrm{~N}$ pool dilution techniques. Such studies on a wide range of soils could be combined with more detailed studies on a more restricted range of soils under field conditions. It is important to determine this ratio because $\mathrm{N}$ fertilizer use efficiencies will be influenced by the preferential uptake and storage of $\mathrm{NH}_{4}^{+}$by the soil microbial biomass. Portions of the residue after $\mathrm{KCl}$ extraction could be subjected to acid hydrolysis and partitioned into various fractions of organic $\mathrm{N}$ (Stevenson, 1996) to give additional information on the forms of organic $\mathrm{N}$ into which microbially immobilized $\mathrm{N}$ has been incorporated.

\section{References}

Azhar, E.S., Verhie, M., Proot, M., Sandra, P., Verstraete, W., 1986. Binding of nitrite-N on polyphenols during nitrification. Plant and Soil 94, 369-382.

Jackson, L.E., Schimel, J.P., Firestone, M.K., 1989. Short term partitioning of ammonium and nitrate between plants and microbes in an annual grassland. Soil Biology \& Biochemistry 21, 409-415.

Mulvaney, R.L., 1996. Nitrogen-inorganic forms. In: Sparks, D.L. (Ed.). Methods of Soil Analysis. Part 3. Chemical Methods. Soil Science Society of America, Madison, WI, pp. 1123-1184.

Puri, G., Ashman, M.R., 1999. Microbial immobilization of ${ }^{15} \mathrm{~N}$-labelled ammonium and nitrate in a temperate woodland soil. Soil Biology \& Biochemistry 31, 929-931.

Recous, S., Mary, B., 1990. Microbial immobilization of ammonium and nitrate in cultivated soils. Soil Biology \& Biochemistry 22, 913-922.

Recous, S., Machet, J.M., Mary, B., 1992. The partitioning of fertiliser-N between soil and crop: comparison of ammonium and nitrate applications. Plant and Soil 144, 101-111.

Rice, C.W., Tiedje, J.M., 1989. Regulation of nitrate assimilation by ammonium in soils and in isolated soil micro-organisms. Soil Biology \& Biochemistry 21, 597-602.

Stevenson, F.J., 1996. Nitrogen-organic forms. In: Sparks, D.L. (Ed.). Methods of Soil Analysis. Part 3. Chemical Methods. Soil Science Society of America, Madison, WI, pp. 1185-1200.

Wickramasinge, K.N., Rodgers, G.A., Jenkinson, D.S., 1985. Transformations of nitrogen fertilisers in soil. Soil Biology \& Biochemistry 17, 625-630.

Widmer, P., Brookes, P.C., Parry, L.C., 1989. Microbial biomass nitrogen measurements in soils containing large amounts of inorganic N. Soil Biology \& Biochemistry 21, 847-865. 